\title{
EXAMINATION OF TEACHERS' OPINIONS ABOUT HOMESCHOOLING SERVICE
}

\author{
Ahmet Yıkmıș ${ }^{1}$, Özlem Toprak ${ }^{2}$, Seniha Kurtoğlu ${ }^{3 *}$ \\ ${ }^{1}$ Abant Izzet Baysal University, Faculty of Education, Department of Special Education, Bolu , Turkey \\ ayikmis@hotmail.com \\ ${ }^{2}$ Sakarya-Erenler Guidance and Research Center-Special Education Teacher \\ asirinn@gmail.com \\ ${ }^{3}$ İstanbul-Ataşehir Special Education Vocational School- Special Education Teacher \\ senihakurtoglu37@gmail.com
}

Correspondence: senihakurtoglu37@gmail.com

\begin{abstract}
The goal of this research is to determine teachers' opinions about the homeschooling service. Teachers participated in the research are the ones provided the homeschooling services in Sakarya City Centre within 2018-2019 school year. Qualitative research method has been used for the research and data has been collected via focus group discussion. Descriptive analysis technique has been used for analysing the obtained data. When the findings of the research are examined, participants who have been providing homeschooling services in a range of one to three years, stated that they had no prior information about homeschooling services, and they enhanced their knowledge level within the process of the education. Every single one of the participants specified that they all practiced observation and evaluation to determine educational performance and the needings of the students during the early weeks of homeschooling service, and afterwards they created individualized education plan (IEP) and figured the educational process according to this plan for their students. The lack of awareness about homeschooling, the families' behaviours and experiencing insufficiency about the supplies are expressed as encountered problems within the homeschooling process. It is emphasized that the homeschooling service increases academic skills of the students while students' distance from their peers and the social environment is a disadvantage.
\end{abstract}

Keywords: homeschooling, focus group discussion, persistent disease

\section{Introduction}

The aim of the education is to create change in human behaviours according to specific goals (Ertürk, 1997). Appropriate and effective education is one of the required and needed necessities for individuals to reach the limit of their actual potentials, and for gaining academic, social, communicational and self caring skills required in the society (ERG, 2009). Every individual should benefit from the educational opportunities according to their special needs.

For individuals with special needs, essential information and skills required to live through both the daily and social life are earned through special education (Gozun and Yikmis, 2004). Special education is stated as "The education that sustained in proper environments with specially trained personnel and the curriculum, which developed to meet the needs of those who significantly differ from their peers in the context of educational adequateness, personal and developmental qualities" in Special Education Services Regulation (MEB, 2018). 
Individuals who need for special education and supportive education services due to persistent disease or sustained care are included within special education service provided individuals (MEB, 2010). Homeschooling services are required to be provided for the continuity of educational life of these individuals. Homeschooling services which are being provided to individuals with special needs who are not able to attend to formal education, have advantages like providing one on one teaching opportunity and immediate inclusion of the family within the educational process (Birkan, 2002). But however, these individuals' lackness of socialising with their peers and staying away from the social environment are the conditions which create disadvantages (Petrie, 1995).

The homeschooling is stated in the Special Education Services Regulation as a service which is provided for those students with special needs who are not able to attend formal education institutions for 12 weeks. Based on the medical board report, this service gets to be provided by The Special Education Evaluation Council. The provided education is planned according to the student's accounted curriculum, and course hours are arranged as mimimum 10 hours a week for those students enrolled in primary education program or in a secondary school applied with special education curriculum; and minimum 16 hours a week for those enrolled in other secondary level schools. For secondary level students, homeschooling service is planned for lessons except shop classes; among the students enrolled in vocational and technical training schools, course of action about the homeschooling service can only be provided for the 9th grade students. The educational needs of the students and the educational programme to follow are taken as a basis during the homeschooling services; special education teachers, preschool teachers, form teachers and other field teachers get to be assigned with the task. The student will be exempted from the courses which are not available to be taught. It is stated in the Special Education Services Regulation that homeschooling service can be provided on the weekends as well as it can be provided on the weekdays. When the literature studies about homeschooling are reviewed, it is seen that studies about the homeschooling are limited, also most of the published studies are about children with special needs and their families.

When abroad research studies about the homeschooling are examined, it is seen that the students get homeschooling service depending on lots of different reasons. It has been noticed that the students took part in these studies get the homeschooling service due to reasons like academic (Winstanley, 2009, Brabant et al., 2003; Collom, 2005; Lubienski, 2003; Ray, 2000; Terry, 2011); religious (Apple, 2000; Basham, Merrifield \& Hepburn, 2007; Brabant et al., 2003; Terry, 2011); cultural factors (Fields-Smith \& Williams, 2009); layout of the school (Princiotta et al., 2006); distrust in schools (Collom, 2005; Princiotta et al., 2006) and the need for special education (Knuth, 2010; Princiotta et al., 2006; Winstanley, 2009).

The research studies which made in our country are investigated; it can be seen that the homeschooling service is not addressed as an alternative educational system that applied within general education, which individuals can prefer to participate in if they are in need to do so (Tasdemir \& Bulut, 2015). Individuals with special needs who can not continue to formal education because of illnesses which require continuous care and treatment get to be included in this service.

Korkmaz and Duman (2014) propounded opinions of 130 Turkish participants about the homeschooling services, via a survey which developed based upon the previous studies about the homeschooling practices in Turkey. Yildirim (2011) aimed for increasing awareness levels of educational authorities and teachers about the continuous illnesses, and developing 
cognitive, affective and physical spatial guidelines for these students within planning processes at schools. As a result of the study, he stated that homeschooling practices are being discussed since 2005, and difference of opinion has been formed between educators and politicians. Y1ldirm and his colleagues (2015) aimed to detect problems which experienced by the individuals with special needs during pre-education, education and posteducation processes in the course of special education process at home. When the findings of the study are examined, it can be seen that the homeschooling program provided for the students who can not attend to school classes is well received by the students and the families, remarkable developments observed with the homeschooling students, and teachers are content with the process. Tasdemir and Bulut (2015) have determined the theoretical pattern of the homeschooling service, and the opinions of the families' with children attending to homeschooling service in Turkey. When the findings of the research are reviewed, it can be noticed that the families state that they consider these services both beneficial and contributive to the development of their children. But they also expressed that they are having problems with teacher and teaching materials during this process. Most of the research about the homeschooling are studies which take the issue in general due to the above-mentioned reasons. Studies about how the teaching is carried out, what are the challenges and needs within the practiceses are quite limited. The need for research originates from this factor.

The aim of this research is to determine teachers' opinions related to the homeschooling practices. Consequently, answers are searched to be found for the questions below:

1. What are the knowledge and experiences of the homeschooling teachers about the provided educational service?

2. How do the homeschooling teachers determine the educational necessities of the students and how do they design the educational process?

3. What are the problems (challenges) that homeschooling teachers encounter within the process?

4. How does the homeschooling service support academic and social skills of the students?

\section{Method}

\subsection{Research Model}

In this research, qualitative research method has been used with the aim of determining the opinions and suggestions of teachers regarding the homeschooling services. The data has been collected via focus group discussion. The focus group discussions are stated as a method of discussion, a group interview that concentrated on a subject of which the boundaries are determined within qualitative research design and methods (Yildirim \& Simsek, 2008).

\subsection{Study Group}

The participants of the research are six homeschooling teachers employed in Sakarya Province. Pre-interviews with homeschooling teachers have been made with telephone calls before the research. After designating the individuals that want to participate in the research, permissions have been received from directorate of national education. After the permission process, the necessary appointments have been made for the interviews. 
Table 1. Participant characteristics

\begin{tabular}{rcccc}
\hline Participant & $\begin{array}{c}\text { Gende } \\
\text { r }\end{array}$ & Branch & $\begin{array}{c}\text { Professional } \\
\text { experience }\end{array}$ & $\begin{array}{c}\text { Experience in } \\
\text { home } \\
\text { education }\end{array}$ \\
\hline Participant A & F & Technology and design & 6 & 2 \\
Participant B & F & Special Education Teacher & 15 & 1 \\
Participant E & M & Classroom Teacher & 20 & 3 \\
Participant F & M & Special Education Teacher & 9 & 1 \\
Participant G & F & Special Education Teacher & 3 & 2 \\
Participant N & F & Special Education Teacher & 5 & 3 \\
\hline
\end{tabular}

\subsection{Data Collection Tools}

Focus group discussion has been used for the research as a medium for data collection. Questions for the interview have been prepared by the researchers based on this context. To get experts' opinions about the interview questions and the research design, two experts that employed in field of special education and also experienced in qualitative research have been asked for their opinions; and the questions have been put into their final form. The revised interview questions are noted below:

\section{TEACHER INTERVIEW QUESTIONS ABOUT HOMESCHOOLING}

\section{Demographic Questions}

1. Hello, how are you? Can you tell us about yourself?

- Which department of university did you graduate from?

- Can you briefly tell us about what are your previous experiences on homeschooling or special education?

What are the knowledge and experiences of the homeschooling teachers about the provided educational service?

1. What are your opinions about homeschooling?

- Did you have any information about homeschooling before providing the homeschooling service? What were your thoughts in this regard?

- What kind of changes did happen in your opinions after providing the homeschooling service?

2. Can you inform us about the academic performance and the needs of the students that you provide the homeschooling service? 
- Which class level do the students belong in?

- Ho do you plan the education in case of every single one of the students belong in different class levels?

How do the homeschooling teachers determine the educational needs of the students and how do they design the education process?

1. When your students' personal features taken into consideration; which lessons are taught to the students in contrast with a normal class?

- Do students take education on every course that included in the curriculum during the homeschooling process?

- Can you explain in which relate do the courses and the subjects presented to the students get to be defined?

- What kind of advantages and disadvantages does the education that provided to the students have in regard to being provided at home?

2. What kind of a process do you follow while determining the performance of the students?

- Can you talk about what kind of method and material do you use while determining students' actual performances?

3. What are your thoughts about preparing IEP (Individualized Education Plan) to your students? Can you share your experiences within this process?

- Can you talk about the preparing process of IEP?

- Which programme did you follow through with the education process of the students? How did you determine the goals?

What are the problems (challenges) that homeschooling teachers encounter within the process?

1. How does getting education in students' homes as their private living space, an informal environment, affect the education process? Do you explain it?

2. How do different conditions and changes happened within the home reflect on the education, can you tell examples about both positive and negative cases that you have experienced? Can you explain them?

3. Can you give information about the methods you use during the education process?

4. Can you give information about the materials you use during the education process?

5. Can you give information about the academic evaluation of the students?

6. How does the process continue about information transferring and student procedures between the schools that your students enrolled to?

How does the homeschooling service support academic and social skills of the students?

1. Can you explain how does the homeschooling contribute to the students in terms of both 
academic and social respects?

2. What are the parents' feedbacks about homeschooling?

3. Can you compare the education that the students taking in home with the education they take in the school? What are the advantages and disadvantages from the point of the student?

Figure 1. The interview form

\subsection{Data Collection}

In the research, face to face interviews have done with the teachers that provide homeschooling service. The place and and the time to take the interviews have arranged with consensus, and the interviews have done in the meeting room of the counseling and research centre which one of the researchers serves in. At the entry part of the interview, the aim of the research has been explained and the permission to record the interview with audio recording device has been granted. The interview has started with participants introducing themselves. 4 basic questions of the research have been asked to the participants during the interview which based on the method of question and answer, and attention has been paid to carry on the interview with mutual interaction. The audio record of the interview has been recorded by using two audio devices in case of preventing data loss.

\subsection{Data Analysis}

The research data have been analysed with descriptive analysis. The descriptive analysis is a type of qualitative analyse which includes summarizing and interpretation of the data collected via various data collection techniques according to the predetermined themes (Yildirim \& Simsek, 2008). The teachers' replies for four research questions and their assistive questions designated for the aim of the research, have been collected via data collection technique of the focus group discussion. The interview has been recorded with audio recording device. Total length of the interview is 55 minutes and 14 seconds. The audio record of the interview has been converted into written data. The converted data resulted in 48 pages, 1548 lines. In addition to this, a code name have been designated for each of the participants, it is stated that their identities will be kept as secret. The participants have been informed about that the interviews will only be listened/read by a second individual just to ensure the reliability of the interview.

\section{Findings}

\subsection{Knowledge and experiences of the teachers about the homeschooling service}

When the participants are asked about their knowledge and experiences about the special education and homeschooling, they stated that two of them have been providing the homeschooling services for 1 year, two of them stated that for 2 years, and the other two stated for 3 years. Due to four of the participants are special education teachers themselves, while they were explaining that they have experience about the special education, they also emphasized that they have no experience about homeschooling service. Because of the other 
two participants came from different fields of education, they emphasized that they have enhanced their experiences about the special education and the homeschooling service within the process. They expressed that they did not start homeschooling services by their own requests, but took part in the process with the guidance of other people. Participants expressed the reasons of beginning to the homeschooling service as "it is because of the headmistress's insistance" (participant E, p.6, line 168-169), "I took a little bit of reactive approach towards the service because it is said that I have to participate in by leaving the weekly course hours at the school, I definitely did not want to go for it at first because if I did so, there will be no one left to take care of my students" (participant B, p.7, line 220-225), "because of the headmaster's insistance... We were not eager about it... But as I mentioned before, there were prejudgements. After these opinions changed, of course we get to set a different kind of bond with them" (participant A, p.9, line 261-265). One of the participants stated that she was involved in the process by getting informed beforehand about homeschooling: "It was talked about the service during Teachers' Day meeting". The participants stated that their thoughts changed positively after they started to provide homeschooling service, that they set a warm relationship with both students and their families: "We are seeing each other... at special days, we call each other when something important happens, we talk about this and that, so I am happy about it, it is going well" (participant A, p.9, line 269-271).

\subsection{Designing of the education process with determining the special needs of students}

The participants stated that when they started homeschooling, the first thing they did was to spare some time to know the family and the student. They emphasized that they form the aims of education after determining the actual performance levels of the students they educate. The participants' statements are: "At first, I met with the parent, family... I learned about... the performance of the student" (participant F, p.11, line 327-329), "I observed the performance for some time... Later, I have prepared an IEP designed for the need" (participant G, p.12, line 359-361), "I have designated and used the studies, activities relevant to the measuring skills. After designating them... while consulting with the parent... I chose the aims, and what to study about the student" (participant F, p.11, line 336-341), "I determined monthly learning outcomes" (participant E; p.12 line 367), "Because of meeting with the student for the first time, we had a familiarization period; I determined their performances" (participant G, p.13, line 393-395). Participants stated that they mostly use visual materials and interesting work sheets within the education activities: "Work sheet activities" (participant G, p.30, line 960). The participants said that they are making the success evaluation during the education process based on the students' individualized education plans and reporting these information to the student's school administration: "I handed them over to the school administration... I hold the examinations..." (participant F, p.32, line 1027-1030).

\subsection{The problems that teachers encounter during the homeschooling process}

When the participants mentioned the problems they came across within the process, it is seen that they generally have problems with 3 basic subjects. Providing students during the education process with materials appropriate with the students and the educational goals: "You need for something but cannot get to it, the material issue is a serious problem... When studying with the kids who do not know how to read and write, who are educated with more 
visual and basic skills, the material becomes a serious problem" (participant B, p.30, line 970-978).

When we look into the problems with family and behaviours, female teachers said that they feel uncomfortable when there is no woman at home, as well as male teachers are said to be feeling the same when there is no man at home: "Only father was at the home... To tell the truth, absence of a woman in the home was stressful for me... It was stressful, and when we look from other families' point of view, mothers want female teachers... because they are the ones generally staying at home." (participant B, p.15, line 475-484). And another participant said that "family's environment, the family relations or the reactions they show when we go there... are also become very important". (participant G, p. 14, line 443-445)

The participants expressed their opinions about the lack of awareness in social environment as follows: "Neighbours came like they are coming to daily women's meeting, started to watch... wondering about the homeschooling" (participant N, p.18, line 552-554), "There was a watchful person, always asking... That we were coming for homeschooling... Homeschooling for what?" (participant E, p.16, line 500-503), "Yes, it is our biggest problem... It is unknown in Turkey" (participant E, p.17, line 545-546). Participant E expressed that he considered to quit providing homeschooling because of the problems he encountered but the family convinced him otherwise, and he keep to proceed as how it was before. The participants from fields other than special education stated that their knowledge level about homeschooling has to be improved.

\subsection{The contribution of homeschooling service on the academic and social skills of the students}

Participants expressed in the interview that when considering the positive contributions of the homeschooling service, students who cannot continue attending to school lessons have the same learning outcomes of the curriculum much effectively with personal education thanks to the homeschooling; "...They are not able to go there but they can get this service, every day, they are not evaluated as absent from school, this is an advantage for the students. Students learning process last longer in the classroom but with the help of one on one studies they can progress faster." (participant F, p.18, line 571-574).

One of the participants stated the contribution of the homeschooling service to the students in social aspects as follows: "Seriously introverted in social manners... Almost forgot to speak, having no friends, sitting all alone in the home and spending almost 6-7 hours a day playing with the tablet..." (participant F, p.22, line 688-692). Participants expressed that the homeschooling is an advantage for the families in social aspects, as well as it is for the students as the following: "Also it is such a nice study for parents... They are already exhausted in psychological aspects, they are not able to go out of the home but parents automatically start to smile as soon as they see me" (participant N, p.19, line 583-590), "The parent of my student was totally focused on the child, taking child to the school and take back again, for the whole day... but now it is different... For instance, the parent started to work in a job" (participant F, p.19, line 612-615).

In contrast with the statements above, some of the participants expressed that the students' being away from their social environment is one of the problems in the process: "Homeschooling... is started to become an advantage for some of the students, as well as a disadvantage for others. 4 students in our school get the homeschooling service. 3 of them, including my student, actually need to attend to the school classes because these children 
regressed drastically in the social aspect. It is my understanding that the child is almost forgot how to talk because of the family communication is not so good, too" (participant B, p.34, line 1099-1109), "If they are not gravely disabled, I think most of the students, especially the special education students, should continue to attend regular classes... in one way or another" (participant B, p.35, line 1131-1135), "After quite a while, the child... the lack of social aspects start to affect other aspects, too" (participant F, p.37, line 1182-1185).

It is seen that the participants shared different experiences and observations because of the nature of the focus group discussion in the research allowed them to answer the questions as it was like chatting, a mutual interaction. They expressed the value added to them by the homeschooling as: "It set a new course... Your perspective on the life changes or it provides you a different point of view, I evaluate the homeschooling in these aspects" (participant E, p.39, line 1253-1256), "It provides a different angle, changes your tutorage. You get sad with a child, you can laugh with the child" (participant E, p.40, line 1284-1287), "My attitude towards other students definitely changed, I notice on myself that I start to take personal differences more seriously" (participant A, p.47, line 1515-1518).

\section{Discussion and Conclusion}

When findings of the research are examined, participants stated one of the problems come out is the lack of the teaching materials, due to the homeschooling being provided within home environment. This finding of the research is similar with findings of the study conducted by Taşdemir and Bulut in 2015. Directorates of National Education can supply the necessary proper materials according to the homeschooling student's class level and needings, and let the teachers to use them to solve the problem about material supply that come into view within the findings. A standard for the homeschooling service can be formed and according to that, supportive material for teaching can be provided.

The participants think that the awareness about the homeschooling and continuous illnesses is not enough. It is seen that this finding is similar with the finding of the study conducted by Y1ldirım in 2011. Informative seminars and educational studies about awareness studies can be arranged for the families, for general education teachers, and for the teachers provide this service. Instructional trainings about the topics of special education, method and techniques, the characteristics of the individuals with continuous illnesses and special needs, the IEP and evaluation can be arranged, especially for the teachers that provide the homeschooling service.

The participants expressed that the problem they were having with the families was a cultural condition which is based upon gender differences. For instance, a female teacher said that she feels uncomfortable in cases when the student's mother is not at home. Likewise a male teacher stated that he feels uncomfortable in cases when the student's father is not at home. Some of the participants mentioned that the situation has changed after some time but some of the participants stated that the situation still continue to last as same as how it was before. In the light of these information shared by the participants, it should be detected if the homeschooling teachers take this education voluntarily or not, and later on it is advised that they should start the process after having a pre-interview with the family of the student who will be educated. 
The participants expressed that the homeschooling service improves the academic and social skills of the students. The participants mentioned that the students learn faster with one on one education as well as feeling much more comfortable in social and communicational aspects. Some of the participants stated that it affects the students negatively in social aspect, that becoming distanced with the school and their peers. To remove this disadvantage, activities that allow the homeschooling students to come together with their peers can be arranged periodically. Also the homeschooling process can be reviewed by teachers on a regular basis, so they can lead those students able to continue attending on formal school classes for guidance and counseling centres to reevaluate their school enrollment results.

In our country, individuals with special needs are having education in schools of general education, special education classes and special education schools. In addition to these, homeschooling service is being provided for the individuals with continuous illnesses. Meeting the educational needs of those students who cannot continue to mainstream schools due to their continuous illnesses and special needs with the help of a teacher by providing one on one education at home, is a positive situation in the aspect of the student's right to be educated. In spite of that, problems encountered during the homeschooling process like teachers' employment, material supply, lack of awareness, students' distance from their peers and the social environment are also negative conditions. In the performed research, studies to eliminate the problems stated by the participants are needed to be conducted on behalf of improving the quality of the homeschooling.

\section{Conclusion and Recommendations}

Within the context of the study, recommendations on application and advance research are included. For the application; trainings to enhance the knowledge and experience for teachers who provide homeschooling service can be arranged before the service. Activities and events with classmates can be organized to support homeschooling students' social development. To speak on behalf of the future research, they can be performed with broader participants and in different regions of the country. Experimental studies that tested the effectiveness and/or performance of different models, methods and techniques can be included in these research. 


\section{References}

Apple, M. (2000). The cultural politics of home schooling. Peabody Journal of Education, 75(2), 256-271.

Basham, P., Merrified, J., \& Hepburn, Claudia R. (2007). Home schooling: From the extreme to mainstream. Vancouver: The Fraser Institute.

Brabant, C., Bourdon, S., \& Jutras, F. (2003). Home education in Quebec: Family first. Evaluation \& Research in Education, 17(2-3), 112-131.

Birkan, B. (2002). Erken ozel egitim hizmetleri. Ankara Universitesi Egitim Bilimleri Fakultesi Ozel Egitim Dergisi, 3(2), 99-109.

Collom, E. (2005). The ins and outs of homeschooling: The determinants of parental motivations and student achievement. Education and Urban Society, 37(3), 307-335.

Evde ve Hastanede Egitim Hizmetleri Yonergesi, (2010). Retrieved from https://orgm.meb.gov.tr/meb iys dosyalar/2012 10/02031840 evde hastanede egitim _hiz_yonergesi.pdf on 01.04.2019.

English, R. M. (2013). The most private private education: Home education in Australia. Homeschool Researcher, 29(4), 1-7.

ERG. (2014). Turkiye egitim sisteminde esitlik ve akademik basari arastirma raporu ve analiz. IIstanbul: Egitim Reformu Girisimi.

Erturk, S. (1997). Egitimde program gelistirme. Ankara: Meteksan.

Fields-Smith, C., \& Williams, M. (2009). Motivations, sacrifices, and challenges: Black parents' decisions to home school. The Urban Review, 41(4), 369-389.

Gozun, O., \& Yikmis, A.(2004). Ilkogretim mufettislerinin kaynastirma uygulamasina iliskin gorus ve onerileri. Ankara Universitesi Egitim Bilimleri Fakultesi Ozel Egitim Dergisi, $5(2), 79-88$.

Korkmaz, H., \& Duman, G. (2014). Public understanding about homeschooling: A preliminary study. Procedia-Social and Behavioral Sciences, 116, 3891-3897.

Knuth, J. D., \& Johnson, S. A. (2010). A descriptive analysis of homeschooling children with autism (Doctoral Dissertation). California State University, Sacramento.

Lubienski, C. (2003). A critical view of home education. Evaluation \& Research in Education, 17(2-3), 167-178.

Ozel Egitim Hizmetleri Yonetmeligi, (2018). Retrieved from https://orgm.meb.gov.tr/meb iys dosyalar/2018 07/09101900 ozel egitim hizmetleri _yonetmeligi_07072018.pdf on 20.03.2019.

Petrie, A. (1995). Home education in Europe and the implementation of changes to the law. International Review of Education, 47(5), 477-500.

Princiotta, D., Bielick, S. \& Chapman, C (2006). Homeschooling in the United States. Washington, DC: U.S. Department of Education, National Center for Education Statistics.

Ray, B. D. (2000). Home schooling: The ameliorator of negative influences on learning?. Peabody Journal of Education, 75 (1/2), 71-106. 
Tasdemir, M., \& Bulut, A. S. (2015). Ev okulu uygulamasi uzerine bir durum calismasi: Kuram ve ozel eggitimde uygulama. International Journal of Eurasia Social Sciences, 6(19), 138-157.

Terry, B. K. (2011). Homeschooling in America a viable option. Retrieved from https://files.eric.ed.gov/fulltext/ED517220.pdf on 10.03.2019.

Winstanley, C. (2009). Too cool for school? Gifted children and homeschooling. Theory and Research in Education, 7(3), 347-362.

Yildirim, A., \& Simsek, H. (2008). Nitel arastirma yontemleri. Ankara: Seckin Yayincilik.

Yildirim, N. (2011). Ogretim surecinde bulunan ogrencilerde gorulen suregen hastaliklar uzerine yonetimsel degerlendirme: Tokat ili ornegi. Balikesir University Journal of Social Sciences Institute, 14(25), 69-85.

Yildirim, N., Talas, S., Yazici, L., Nural, H., Celebi, I., Cetin, K., \& Caylak, M. (2015). Evde egitim alan ogrencilerin egitim sureclerinin degerlendirilmesi (Tokat Ili Ornegi). Egitim Kuram ve Uygulama Arastirmalari Dergisi, 1(1), 33-52. 